\title{
EPA IMPACT STATEMENTS REQUIRED UNDER CLEAN AIR ACT
}

In Anaconda Co. v. Ruckelshaus ${ }^{1}$ the District Court for the District of Colorado held that, under section 102(2)(C) of the National Environmental Policy Act (NEPA), ${ }^{2}$ the Environmental Protection Agency (EPA) is required to file an environmental impact statement ${ }^{3}$ before promulgating a Clean Air Act state implementation plan. ${ }^{4}$ In accordance with section 110 of the Clean Air Act Amendments of $1970,{ }^{5}$ the governor of Montana had submitted an implementation plan to EPA for approval. ${ }^{6}$ EPA specifically rejected certain aspects of the plan, citing in particular the plan's failure to provide a control strategy for sulphur oxides emissions from nonferrous smelters, ${ }^{7}$ and subsequently proposed its own implementation plan $^{8}$ for emissions limitation on those sulphur oxides. ${ }^{9}$ The Anaconda Company, a large Montana copper smelter, sought to enjoin implementation of the proposed EPA plan pending preparation

1. 352 F. Supp. 697 (D. Colo. 1972).

2. 42 U.S.C. $\$ \S 4321-47$ (1970).

3. An environmental impact statement is described in NEPA as a detailed statement on the environmental impact of a proposed agency action, including the unavoidable adverse effects, the alternatives, and the resources to be committed. See 42 U.S.C. \& 4332(c) (1970). These statements must be inade available to the President, the Council on Environmental Quality, and the public. Id. For an analysis of the response of various federal agencies to this mandate, see Address by Mr. Baldwin, Law Forum and Environmental Law Society of Stanford Law School, Dec. 9, 1970, reprinted in F. Grad, Environmental LaW, Sources and Problems $\$ 13.01$, at 19 (1971).

4. 42 U.S.C. $\$ 1857$ (1970). A state implementation plan sets forth the maximum amount of air pollution emissions which will be permitted from specific sources within a specific geographic area, and also sets a timetable for comphance with these emission standards. The standards must be based on the underlying federal "air quality criteria" required by section 109 of the Clean Air Act Amendments of 1970. See id. \& 1857c-4.

5. Id. § 1857c-5.

6. Approval by EPA can only be granted if the state plan or plans meet primary and secondary air quality standards set by the federal government under section 109 of the Act.

7. Sulphur oxides are common by-products from the smelting of non-ferrous metals such as copper.

8. Section $110(\mathrm{c})$ requires EPA to prepare and publish proposed regulations setting forth all or part of an implementation plan for a state if that state has failed to submit an implementation plan, if a plan or portion thereof has failed to meet the requirements of the Act, or if a state has failed to revise a deficient implementation plan within a specified period of time. 42 U.S.C. $\$ 1857 \mathrm{c}-5$ (c) (1970).

9. 352 F. Supp. at 700 . 
of an environmental impact statement pursuant to section 102(2) (C) of NEPA. EPA responded that the legislative history of NEPA made it clear that the Act was not intended to apply to an agency such as EPA. ${ }^{10}$ In rejecting the EPA argument, the court held that, if regulations will have a significant effect upon the environment, an enviromental impact statement unust be prepared by the EPA before those regulations could be implemented under the Clean Air Act. ${ }^{11}$

NEPA was intended both to impose a broad scope of environinental responsibility upon federal agencies and to insure that federal agencies would not unnecessarily contribute to environmental deteriorarion. ${ }^{12}$ In furtherance of these purposes, the Act prescribes

10. Id. at 710. EPA argued further, $i d$. at 713 , that any doubts in this regard had been erased by a provision in section 511(c) of the Federal Water Pollution Control Amendments:

[N]o action of the [EPA] Administrator taken pursuant to this Act shall be deemed a major Federal action significantly affecting the quality of the human environment within the meaning of the National Environmental Policy Act of 1969 .... Pub. L. No. 92-500, \& 511(c) (Oct. 18, 1972), reprinted in U.S. CODE CONG. \& AD. NEWS 4825, 4919 (1972).

11. Although beyond the scope of this discussion, two other major issues were resolved in this case. EPA contended that section 307 of the Clean Air Act, 42 U.S.C. ₹ $1857 \mathrm{~h}-5$ (1970), which provides for review by petition to circuit courts of appeal for already promulgated state plans, barred a suit in federal district court to enjoin an EPA proposed implementation plan. $352 \mathrm{~F}$. Supp. at 710-11. The court held that section 307 did not bar the suit because the proposed plan had not yet been implemented and thus no review was available to Anaconda under section 307. In response to Anaconda's argument that EPA was required to hold an adjudicatory hearing before promulgating an EPA proposed implementation plan, the court ruled that the hearing must be held because the plan applied solely to Anaconda. Id. at 703. EPA plans to appeal the decision in the Anaconda case. See Statement of John R. Quarles, Jr., Dec. 11, 1972, cited in 3 ENVIRONMENTAL L. REP. 940 (Dec. 15, 1972).

12. Section 101(a) of NEPA declares the national environmental policy:

The Congress ... declares that it is the continuing policy of the Federal Government . . . to use all practical . . ineasures . . . in a manner calculated to foster and promote the general welfare, to create and maintain conditions under which man and nature can exist in productive harmony, and fulfill the social, economic, and other requireinents of present and future generations of Americans. 42 U.S.C. $\$ 4331$ (a) (1970).

After setting out the objectives of the national policy, section 101(b) declares that through the improvement and coordination of federal plans, functions, and programs, the Nation may,

(3) attain the widest range of beneficial uses of the environment without degradation, risk to health or safety, or other undesirable and unintended consequences. Id. $\$ 4331(\mathrm{~b})$.

For examination of the purposes of NEPA in more detail, see Peterson, $A n$ Analysis of Title $I$ of the National Environmental Policy Act of 1969, 1 BNA ENVIRONMENTAL L. REP. 10035 (1970); Note, The National Environmental Policy Act: A Sheep in Wolf's Clothing?, 37 BrookLYN L. REv. 139 (1970); Note, NEPA: Birth and Infancy, 20 CATH. U.L. Rev. 184 (1970). 
both substantive and procedural duties for federal agencies. The substantive thrust is delivered primarily in section 102(1):

The Congress authorizes and directs that, to the fullest extent possible: (1) the policies, regulations, and public laws of the United States shall be interpreted and administered in accordance with the policies set forth in this [Act] .....13

The Act's legislative history reveals that the phrase "to the fullest extent possible" provides a limited exception to compliance with the substantive duties of NEPA for agencies granted independent, statutory environmental responsibility; to the extent that another statute expressly prohibits or makes compliance with one or more sections of NEPA impossible, such an agency is exempt from compliance. ${ }^{14}$ The procedural requirements of NEPA are set forth in section 102(2). ${ }^{15}$ The most important of these, section 102(2)(C), requires federal agencies to prepare a detailed statement of potential environmental impact for "major federal actions significantly affecting the quality of the liuman environment."18 The legislative history does not specifically indicate whether, in the absence of express statutory conflict, these procedural requirements were intended to apply to the regulatory programs of agencies, such as EPA, with independent, environmental responsibility.

The Council on Environmental Quality (CEQ), which is authorized to issue advisory guidelines to federal agencies for the implementation of section 102(2)(C), ${ }^{17}$ has determined, on the basis of its reading of NEPA's legislative history, that section 102(2)(C) is totally inapplicable to EPA. ${ }^{18}$ The CEQ Guidelines provide that the regulatory activities taken by EPA will not be deemed actions which require the preparation of environmental impact statements. In the Guidelines, lowever, CEQ did not state what portions of the legislative history led to this interpretation. The most persuasive support for CEQ's position is found in the report of "Major Changes in S.1075

13. 42 U.S.C. $\$ 4332(1)$ (1970).

14. See H. REP. No. 765, 91st Cong., 1st Sess. (1969), where it is stated:

The purpose of the ... language [to the fullest extent possible] is to make it clear that each agency of the Federal Government shall comply with the directives set out im such subparagraphs $(A)$ through $(H)$ unless the existing law applicable to such agency's operations expressly prohibits or makes full compliance with one of the directives impossible. Id. at 9.

15. 42 U.S.C. $\$ 4332(2)(1970)$.

16. $I d$.

17. CEQ was granted this authority by an executive order. See Exec. Order No. $11,514,3$ C.F.R. 526, 528 (1972).

18. CEQ Guidelines § 5(d), 36 Fed. Reg. 7724, 7725 (1971). 
as passed by the Senate" (the senate version of NEPA). ${ }^{10}$ In reference to environmental protective agencies such as the National Park Service, the Federal Water Pollution Control Adininistration, and the National Air Pollution Control Administration, the report stated:

The provisions of section $102 \ldots$ are not designed to result in any change in the manner in which [these agencies] carry out their environmental protection authority. ${ }^{20}$

Six months after the passage of NEPA, the EPA was established and assumed the functions of the Federal Water Pollution Control Administration and the National Air Pollution Control Administration. ${ }^{21}$ Thus, if it can be assumed that "any change in the manner" in which agencies carry out their environmental protection authority refers to procedural as well as substantive matters, the EPA should be exempt from section 102(2)(C) of the NEPA.

The validity of CEQ's conclusion, however, is doubtful; the substance of section 102's legislative history may not have been directed at the procedural provisions, but only at the substantive obligations of that section. A further statement found in "Major Changes to S.1075," in reference to the phrase "to the fullest extent possible,"22 indicates that the phrase "shall not be used by any Federal agency as a means to avoiding [sic] compliance with the [procedural requirements] set out in Section 102."23 Moreover, NEPA's sponsor, Senator Jackson, stated during the debate preceding passage of the bill that any deviation from full compliance with the substantive goals of NEPA must be "justified in light of public scrutiny as required by section 102"- that is, by an impact statement. ${ }^{24}$ Thus, as can be seen, the legislative history of NEPA is, at best, inconclusive as to whether Congress intended the procedural requirements of section 102 to apply to an environmental protection agency such as the EPA. Congressional intent in this area is also difficult to discern, because the NEPA hearings focused chiefly on the water and air programs; yet EPA, established six months after the passage of NEPA, assumed control not only over the water and air programs ${ }^{25}$ but also

19. 115 Cong. REc. 40417 (1969) (report of the Senate conferees to the Senate).

20. Id. at 40418 (emphasis added).

21. EPA was established and these programs transferred to it by Executive Reorganization Plan No. 3 of 1970. See 3 C.F.R. $\$ \$ 199-200$ (1970). See note 26 infra.

22. 42 U.S.C. $\$ 4332(1970)$. See note 13 supra and accompanying text.

23. 115 CoNG. REC. 40418 (emphasis added).

24. Id. at 40416 (emphasis added).

25. See note 21 supra. 
substantial control over pesticides, radiation, and solid wastes disposal, ${ }^{26}$ areas virtually ignored during the discussions in the NEPA hearings of section 102 .

Although the legislative history of NEPA may be inconclusive as to this issue, it is clear that the EPA was intended to coordinate and give coherence to the broad environmental policies contained im NEPA. ${ }^{27}$ EPA has taken the position that NEPA was designed only to insure that the non-environmental, "mission-oriented" agencies would consider environmental values in decision making. ${ }^{28} \mathrm{Be}-$ cause of the central role EPA plays in the protection of the environment, it is apparent that the agency's function differs markedly from the non-environmental "mission-oriented" agencies. Contending that this role gives it a broader environmental "perspective," 29 EPA

26. The programs transferred to EPA under Reorganization Plan No. 3 of 1970, supra note 21, include: (1) functions with respect to pesticide studies, from the Department of the Interior; (2) the pesticides registration program of the Agriculural Research Service, from the Department of Agriculture; (3) the pesticides research and standard-setting programs limiting pesticide residues in food, from the Food and Drug Administration; (4) the environmental radiation standards programs establishing environmental radiation standards and emissions limits for radioactivity, from the Atomic Energy Commission and the Federal Radiation Council; (5) functions carried out by the Bureau of Solid Waste Management, from the Department of Health, Education and Welfare. See Message of the President Relative to Reorganization Plans Nos. 3 and 4 of 1970, H.R. Doc. No. 366, 91 st Cong., 2d Sess. 2-3 (1970).

Environmental responsibihties not transferred to the EPA include, inter alia, authority of the Food and Drug Administration to remove from the market food with excess pesticide residues, authority of the Atonnic Energy Commission to implement and enforce radiation standards through its licensing authority, and regulation of radiation from consuner products by the Department of Health, Education and Welfare. Id. at 4.

27. In formulating the recommendation for the creation of the Environmental Protection Agency, the President's Council on Executive Reorganization stated one of the agency's objectives to be "[r] prehensive view of ... the planet's ecology, the economic costs of pollution and its abatement, considering also the benefits ... that may accrue from the . . . activities that give rise to pollution." Hearings on Reorganization Plan No. 3 of 1970 Before a Subcomm. of the House Comm. on Governmental Operations, 91st Cong., $2 \mathrm{~d}$ Sess. 46 (1970). President Nixon, in a message to Congress accompanying the reorganization plan which established the EPA, noted that the need for NEPA arose because

[o] ur national government today is not structured to make a coordinated attack on the pollutants which debase [the environment]. Indeed, the present governmental structure for dealing with environmental pollution often defies effective and concerted action. Message of the President Relative to Reorganization Plans Nos. 3 and 4 of 1970, supra note 26, at 1.

28. Joint Hearings on the Operation of the National Environmental Policy Act of 1969 Before the Committees on Public Works and Interior and Insular Affairs, 92d Cong., 2d Sess. 546 (1972) (statement of Wilham D. Ruckelshaus).

29. Mr. Ruckelshaus, in arguing that section 102(2)(C) of NEPA as applied to 
has argued that its role makes the procedural requirements of NEPA unnecessary. ${ }^{30}$ However, EPA's argument is weakened by the refusal of courts, in ruling on the applicability and scope of NEPA's procedural provisions, to differentiate between those agencies with environmental improvement authority and the other agencies which are merely guided by NEPA generally. ${ }^{31}$ For example, the semmal case on NEPA applicability, Calvert Cliffs' Coordinating Committee v. $A E C,{ }^{32}$ dealt with a "non-environmental" agency, the Atomic Energy Commission. The Court of Appeals for the District of Columbia Circuit read literally the "all Federal agencies" phrase of section 102(2), ruling that the procedural duties of NEPA are mandatory and bimding upon the AEC and all federal agencies. ${ }^{83}$ Since the AEC did not have an independent environmental mandate, it was not necessary for the court to decide whether imdependent, statutory environmental responsibility would affect the applicability of NEPA. The decision, however, has been subsequently im-

the EPA would be superfluous, has stated:

We wouldn't be doing our job if we did not consider within the agency

all of the alternatives in adopting standards . ....

If we did not do that ... we would not even be close to discharg-

ing our respousibilities as an agency. Id. at 555.

Since under this argument EPA's mission is solely environmental, it is entirely unnecessary to impose the additional and redundant burden of preparing impact statements for EPA regulatory activities. Id. at 556.

30. This position is weakened by EPA's express declaration in Anaconda that, when promulgating Clean Air Act implementation plans, only air pollution factors will be considered. See notes $49-51$ infra aud accompanying text.

31. See notes 34-35 infra. However, in ordering EPA to reconsider its rejection of four major automobile manufacturers' application for suspension of the 1975 emission standards for light duty vehicies pursuant to section 202 of the Clean Air Act, 42 U.S.C. $\$ 1857 f-1$ (b) (5)(B) (1970), the Court of Appeals for the District of Columbia Circuit, in International Harvester Co. v. Ruckelshaus, - F.2d - (D.C. Cir. 1972), stated:

Although we do not reach the question of whether EPA is automatically and completely exempt from NEPA, we see little need in requiring a NEPA
statement from an agency whose raison d'etre is the protection of the environment, and whose decision on suspension is necessarily infused [by the Clean Air Act, \& 202 (b) (5) (D), 42 U.S.C. $\$ 1857 \mathrm{f}-1$ (b) (5)(D) (1970)] with . . . environmental considerations. - F.2d at - (emphasis added). The court was impelled to this conclusion by its belief that to require an environmental impact statement, in addition to EPA's suspension decision setting forth the same considerations, would be "a legalism carried to the extreme." Id. at - . In Anaconda, however, EPA contended that it could not consider environinental factors other than air pollution in evaluating state implementation plans for primary and secondary national ambient air standards. 352 F. Supp. at 704. See notes 49-51 infra and accompanying text.

32. 449 F.2d 1109 (D.C. Cir. 1971).

33. Id. at $1114-15$. 
terpreted to apply to environmental protective agencies such as the Forest Service ${ }^{34}$ and the Army Corps of Engineers. ${ }^{35}$

In Anaconda, EPA raised two alternative arguments to support the agency's contention that it was exempt from the procedural requirements of NEPA. First, EPA contended that the 1972 amendments to the Federal Water Pollution Control Act (FWPCA) ${ }^{36}$ had been intended to exempt EPA activities from NEPA. The court summarily rejected this contention, however, and pointed out that the language of the FWPCA ${ }^{37}$ was obviously intended only to renove regulatory activities performed under that Act froin the procedural requirements of NEPA. ${ }^{38}$ EPA's second argument was based upon the agency's reading of a 1972 decision handed down by the Court of Appeals for the Third Circuit, Getty Oil Co. v. Ruckelshaus. ${ }^{38}$ In Getty, the plaintiff had contended that EPA's failure

34. In Upper Pecos Ass'n v. Stans, 452 F.2d 1233 (10th Cir. 1971), the Tenth Circuit recognized the duty of the Forest Service to prepare an environmental impact statement in connection with the building of a national highway. The court apparently attached no significance to the environmental status of the agency, ruling that the Forest Service was obligated to prepare the statement because it was the "lead" agency-the agency which had primary responsibility for the project. Id. at 1236.

35. In EDF, Inc. v. Corps. of Eng'rs, 470 F.2d 289 (8th Cir. 1972), the Eighth Circuit affirmed a lower court's ruling that the Corps of Engineers was required to file an impact statement in the construction of a dam, basing its decision on the assumption that NEPA applies indiscriminately to all federal agencies. Id. at 295 . An earlier district court case, Kalur v. Resor, 335 F. Supp. 1(D.D.C. 1971), expressly raised, for the first time, the issue of whether an environmental protective agency is exempt froin the filing of section 102 statements. In Kalur, several plaintiffs a1leged that an Army Corps of Engineers regulation exempting Refuse Act discharge permits from the NEPA section 102 requirements was invalid. The court upheld this contention, stating that all agencies are bound by NEPA and that there is "no exception . . . carved out for those agencies that may be viewed as environmental improvement agencies." Id. at 15 . In a 1972 case similar to Kalur, Sierra Club v. Sargent, - F. Supp. - (W.D. Wash. 1972), the plaintiffs also sought to enjoin issuance of a Refuse Act permit issued by the Corps of Engineers. The injunction was sought partially on the theory that impact statements were required by NEPA prior to issuance of the permits. In Sierra Club, the Corps had advanced the same argument now utilized by the EPA in Anaconda: unlike many other agencies, the Corps is an environmental protective agency and will therefore autonatically consider environmental factors, making the requirement of an impact statement duplicative and wasteful. In its order, the court rejected this argument and ruled that the Corps of Engineers was required to prepare an environmental impact statement before issuance of the permit. Id. at -

36. Pub. L. No. 92-500, §511(c) (Oct. 18, 1972).

37. See note 10 supra.

38. 352 F. Supp. at 713.

39. 468 F.2d 349 (3d Cir. 1972). 
to prepare an environmental impact statement rendered ultra vires an EPA enforcement order directing compliance with a previously approved air quality plan. ${ }^{40}$ The Third Circuit found it unnecessary to rule on the contention, holding that the NEPA issue could be properly raised only in a proceeding initiated within thirty days of the promulgation of such plans and not during the enforcement period. ${ }^{41}$ However, the court nevertheless noted that, in any event, the cases cited by the plaintiff, ${ }^{42}$ Getty Oil Co., were "not persuasive that the EPA was bound by NEPA."43 The Anaconda court disagreed with the Third Circuit's dictum, ${ }^{44}$ holding that EPA was so bound. Following the reasoning of Calvert Cliffs', ${ }^{45}$ Judge Winner also refused to differentiate between environmental and non-environmental agencies, and found that the Calvert Cliffs' ruling ${ }^{40}$ and subsequent cases $^{47}$ were accurately descriptive of NEPA's mandatory nature. He ruled that the language "all federal agencies" in section 102 was dispositive and concluded that Congress intended all agencies under their authority to follow the substantive and procedural inandates of NEPA. ${ }^{48}$

The Anaconda court also displayed great concern that EPA had insisted that in determining proper air emission standards the agency could not and "will not consider . . . environmental factors" other than air pollution. ${ }^{49}$ EPA had contended that the Clean Air Act mandates only consideration of air pollution in evaluating state inplementation plans. ${ }^{50}$ The court found EPA's position to be con-

40. Id. at 359 .

41. See id. The Getty court interpreted section 307 of the Clean Air Act, 42 U.S.C. $\$ 1857 \mathrm{~h}-5(\mathrm{~b})(2)(1970)$, as absolutely precluding review of alleged procedural failings during approval and promulgation of state plans after the section 307 thirty-day period had expired. Id. See pp. 253-73 infra.

42. 467 F.2d at 359 n.17, citing Kalur v. Resor, 335 F. Supp. 1 (D.D.C. 1971); EDF, Inc. v. Hardin, 325 F. Supp. 1401 (D.D.C. 1971).

43. 467 F.2d at 359 n.17.

44. 352 F. Supp. at 710 . Section 307 of the Clean Air Act did not bar a federal district court suit in Anaconda because EPA's proposed plan had not yet been promulgated. Id. at 702 .

45. Calvert Cliffs' Coordinating Comm. v. AEC, 449 F.2d 1109 (D.C. Cir. 1971).

46. See notes 32-33 supra and accompanying text.

47. E.g., Davis v. Morton, - F.2d - (10th Cir. 1972); EDF, Inc. v. Corps of Eng'rs, 470 F.2d 289 (8th Cir. 1972); Upper Pecos Ass'n v. Stans, 452 F.2d 1233 (10th Cir. 1971); Kalur v. Resor, 335 F. Supp. 1 (D.D.C. 1971). See also cases cited in - F. Supp. at -.

48. 352 F. Supp. at 710; see id. at 711-13.

49. Id. at 705 .

50. Id. Apparently EPA based its argunnent on subsections 110(a)(2) and 
trary to the requirements of NEPA, ${ }^{51}$ and quoted with favor the $\mathrm{Cal}$ vert Cliffs' ruling that if a substantive decision affecting the environment were "reached procedurally without individualized consideration and balancing of environmental factors . . . it is the responsibility of the courts to reverse."'s2

Although EPA does not now prepare impact stateinents for its regulatory activities, the agency has indicated that it makes every effort to carry out the broad purposes of NEPA, including consideration of overall environmental effects of those actions. ${ }^{53}$ In practice, however, EPA recognizes that it does not always consider the full range of environmental factors envisioned by NEPA. In Anaconda, for example, EPA contended that the Clean Air Act specified that only environmental factors relating to air pollution could be considered in the establishment of air quality standards. ${ }^{54}$ Thus, the fact that reduction of gaseous sulphur oxides might result not only in great economic cost but also water pollution in the form of sulphuric acid, was not a consideration in EPA's promulgation of the sulphur oxides regulation directed at Anaconda. ${ }^{55}$ The narrow view of environmental responsibility demonstrated by EPA in Anaconda runs counter to NEPA-which was not designed to operate independently of other environmental legislation, but rather was intended "to supplement existing, but narrow and fractionated, Congressional declarations of environmental policy." vironmental considerations to be taken into account under the Clean Air Act-or any other statutory basis for regulatory environmental

(3) of the Clean Air Act, 42 U.S.C. $\$ \$ 1857 c-5(a)(2)-(3)$ (1970), which lists criteria to be used for EPA approval of a state implementation plan. These criteria encompass only air pollution considerations and may be contrasted with the criteria under section 202(b)(5)(D) of the Act to be employed by EPA in ruling on an application for suspension of the 1975 emission standards for light duty vehicles, which include public interest, public health, and the welfare of the country. Id. $\S 1857 \mathrm{f}-1(\mathrm{~b})(5)(\mathrm{D})$. See note 31 supra.

51. 352 F. Supp. at 710 . See 42 U.S.C. $\$ 4332$ (1970).

52. 449 F.2d at 1115 .

53. Joint Hearings, supra note 28, at 549-50 (statement of William D. Ruckelshaus).

54. 352 F. Supp. at 710. See also Joint Hearings, supra note 28 , where it is stated:

We do not think that NEPA applies to the setting of such standards so as to require EPA to balance considerations of public health against economic or other considerations, since this would be a clear violation of the Clean Air Act mandate. Id. at 567 (Letter of William D. Ruckelshaus to Senator Howard Baker, May 23, 1972). See note 50 supra.

55. 352 F. Supp. at $710,713$.

56. S. REP. No. 296, 91st Cong., 1st Sess. 9 (1969). 
activity-may be the primary, but not the exclusive, considerations for the environmental "balancing" NEPA requires. ${ }^{57}$ Because of EPA's central role in the protection and enhanceinent of the environment, its primary responsibility should be the careful balancing of competing environmental and economic considerations envisioned by NEPA. Proper "balancing" can be insured by requiring EPA to adhere to the procedural provisions of section 102 of NEPA. In view of the failure of EPA to adequately balance environmental and economic factors in Anaconda, and the weakness of the legislative history arguments advanced by EPA and CEQ, it cannot be said that the Anaconda court erred in concluding that Congress intended all federal agencies to file impact statenents before embarking upon regulatory activities.

Although the Anaconda holding applies to regulatory activities under the Clean Air Act, the reasoning clearly could be extended to EPA's other regulatory programs. Should NEPA's procedural requirements be found applicable to all the regulatory activities of EPA, it would appear that EPA will have to undertake major changes in its règulatory procedures. EPA believes that the disadvantages of the burden of preparing impact statements, for all regulatory activities which would be designated as major federal actions having a significant impact upon the environment, might more than offset the advantages accruing to the public. ${ }^{58}$ There is some evidence supporting this assertion. For example, the pesticides registration program $^{59}$ processed almost 4500 applications for new pesticides registration, 8500 renewals of registrations, and over 10,000 amendments to existing registrations in fiscal $1971 .^{60}$ In comparison, all federal agencies combined filed only 2388 impact statements from the passage of NEPA in 1969 through January 31, 1972, of which

57. This appears to be consistent with the House Conference Report on NEPA which stated:

[I]t is the intent of the [House] conferees that the provision "to the fullest extent possible" [in $\S 102$ of NEPA] shall not be used by any Federal agency as a means of avoiding compliance with the directives set out in section 102. Rather, the language of section 102 is intended to assure . . . that no agency shall utilize an excessively narrow construction of its existing statutory authorizations to avoid compliance. H. REP. No. 765, supra note 14 , at 9-10 (emphasis added).

58. Joint Hearings, supra note 28, at 550 (statement of William D. Ruckelshaus).

59. The pesticides registration program was transferred to the newly created EPA from the Department of the Interior under Reorganization Plan No. 3 of 1970, supra note 21.

60. Joint Hearings, supra note 28, at 548 (Statement of William D. Ruckelshaus). 
only 19 were filed by EPA. ${ }^{61}$ It is obvious that even if only a small percentage of the pesticide permits were found to be "major federal actions" within the meaning of section $102,{ }^{62}$ the EPA's workload in this area would imcrease many times over, with concomitant cost and delay. Air pollution and radiation activities of EPA might also occasion a significant increase in that agency's workload should impact statements be required for major regulatory actions. ${ }^{63}$

There are several ways, however, by which the difficulties of preparing statements can be minimized if NEPA is applied to regulatory activities. The most readily apparent solution is for Congress to provide selective, legislative relief for those regulatory ac-

61. Id. at 14 (statement of CEQ Chairman Russell E. Tram). These figures were compiled by the CEQ.

The environmental impact statements filed by the EPA were for waste treatment facilities construction and water quality management plans approval; none were prepared in connection with EPA regulatory activities. Id. at 580-81 (letter from Sheldon Meyers, Director of the Office of Federal Activities of EPA to Timothy Atkeson, General Counsel of CEQ, April 7, 1972).

62. 42 U.S.C. $\$ 4332$ (1970).

63. Section 108(a) of the Clean Air Act requires EPA to publish lists of newly discovered harmful air pollutants. Id. $\$ 1857 \mathrm{c}-3$. EPA must subsequently promulgate primary and secondary national ambient air quality standards for these pollutants under section 109 (a)(2), id. $\$ 1857 \mathrm{c}-4(\mathrm{a})(2)$, and regulate the sale and use of fuels under section 211(c), id. \$1857f-6c(c). See Greco, The Clean Air Act Amendments of 1970: Better Automotive Ideas from Congress, 3 ENVIRONMENTAL L. REP. 169 (1972); Note, Clean Air Act Amendments of 1970: A Congressional Cosmetic, 61 Geo. L.J. 153 (1972). See also Envtronmental Reporter Federal REgULATIONS $\$ 121$ (1973) (compilation of EPA regulations).

EPA has two primary fnnctions in regard to radiation protection guidance and standards. The first involves the formulation of basic federal policies on radiation protection and promulgation of Radiation Protection Guidelines which will be applicable to all federal agencies concerned with radiation control. This responsibility was assumed under Reorganization Plan No. 3 of 1970, supra note 21, at 200, from the now defunct Federal Radiation Council, Pub. L. 86-373 $\$ 1(\mathrm{~h}), 73$ Stat. 688 (1959). The second function is the establishment of environmental protection standards which limit radiation levels for areas adjacent to radiation-producing installations such as nuclear power plants. Reorganization Plan No. 3 of 1970 , supra note 21, at 200. See Environmental Protection Agency, ENVIRONMENTAL REPORTER $51: 1601$, at 51:1622-24 (1973).

Since EPA itself is unsure as to the ultimate feasibility of preparing impact statments for its own regulatory activities, it has initiated a study to consider the effects of the section 102 process upon its own regulatory activities. Joint Hearings, supra note 28, at 546 (statement of William D. Ruckelshaus). This study should provide much needed information on the capabilities of NEPA to prepare impact statements and perliaps will suggest alternatives to a complete exemption of EPA regulatory activities from NEPA. Although a draft of the study has been completed it is not yet available. Letter from Alan W. Eckert, Attorney Advisor, EPA to Duke Law Journal Feb. 21, 1973. 
tivities where the preparation of impact statements is not feasible, as Congress has done in the 1972 Federal Water Pollution Control Act Amendments exempting EPA from NEPA's requirements in issuing Refuse Act permits. ${ }^{64}$ At least one source has suggested, however, that the best solution is not to exempt EPA completely from the NEPA requirements, but rather to allow EPA and all agencies greater procedural flexibility in coping with the general demands of NEPA. ${ }^{65}$ Another possible means by which EPA might reduce the number of section 102 statements would be to group together regulatory programs or similar projects having a "common thread" so as to make possible a single, comprehensive environmental statement which would include detailed consideration of special circumstances. $^{.8}$ Thus the "balancing" and "trade-off of values" inherent in NEPA ${ }^{67}$ could be preserved, while the administrative burdens in the preparation of many overlapping, individual impact statements are simultaneously minimized.

64. See note 10 supra. The Joint Conference Report on the FWPCA stated that:

If the actions of the [EPA] Administrator under this Act were subject to the requirements of NEPA, administration of the Act would be greatly impeded. S. REP. No. 1236, 92 d Cong., 2d Sess. 149 (1972).

65. Joint Hearings, supra note 28, at 505 (statement of George C. Freeman, environmental attorney). Under this approach agencies could still be required to perform the "balancing" NEPA envisions, but administrative cost and delay could be reduced by allowing an agency to substitute less stringent procedural requirements when strict adherence to section $102(2)(C)$ of NEPA would be unduly burdensome.

66. This might be appropriate on an industry-wide basis (as in the case of regulations concerning radiological health), on a geographic basis (for example, regulations based on a single, comprehensive examination of all air polluters in a given region), or a combination of both approaches. For a general discussion of "grouping," see Kalur v. Resor, Water Quality and NEPA's Application to EPA, 2 BNA ENVIRONMENTAL L. REP. 10,025, 10,028-29 (1971).

67. See Calvert Cliffs' Coordinating Comm. v. AEC, 449 F.2d 1109, 1123 (D.C. Cir. 1971). 